Millatī, Journal of Islamic Studies and Humanities

Vol. 5, No. 1, June 2020: p. 1-15. DOI: 10.18326/mlt.v5i1. 1-15

p-ISSN : 2541-3627 ; e-ISSN 2540-9964

Website: http://millati.iainsalatiga.ac.id/index.php/millati/index

\title{
Declaring Tafseer for Humanity: Tafseer Methodology of Hassan Hanafi
}

Miftahuddin

IAIN Salatiga, Indonesia

miftabuddin@iainsalatiga.ac.id

\begin{abstract}
The purpose of this study is to construct the tafseer methodology of Hassan Hanafi in which he applies a new way of reading texts. The methodology used in this research is descriptive method using content analysis of literature. The main finding of this article is the existence of a new model of reading the text (Qur'an) offered by Hassan Hanafi in his Tafseer method. The uniqueness of the Tafseer methodology is the effort to incorporate social reality into the text. Departing from this reality, the text is "engineered" to overcome humanitarian problems. Thus the meaning of the text is directed to provide theological direction for efforts to solve human problems. In Hassan Hanafi's view, the text must be the theological foundation for humanitarian action. The essence of his specific view is that Tafseer does not pretend to seek universal meaning, but it looks for the temporal meaning that the Qur'an gives to certain generations by ignoring past and future interests. This kind of Tafseer always refers to the experience of Tafseer and its contemporary problems which put more emphasis on solving human social problems (al-manhaj al-tafsir al-ijtima'i) in the present context. The original aspect of this research is the reconstructing of Hassan Hanafi's thoughts in understanding the Qur'an progressively in opposition to the main mainstream Tafseer of the Qur'an in Muslim circles.
\end{abstract}

Keywords: Methodology, Hermeneutics, Humanitarian Tafseer, Thematic Tafseer.

\begin{abstract}
Abstrak
Tujuan studi ini adalah untuk mengkonstruksi metodologi tafsir Hassan Hanafi dimana ia menerapkan cara baru dalam pembacaan Teks. Metodologi yang digunakan dalam penelitian ini adalah metode deskriptif dengan menggunakan analisis isi (content analisys) terhadap literature-literatur pustaka. Temuan utama dari artikel ini adalah adanya model pembacaan baru terhadap Teks (al-Qur'an) yang ditawarkan oleh Hassan Hanafi dalam metode tafsirnya. Keunikan dari metode tafsirnya adalah pada upaya untuk memasukkan realitas sosial ke dalam Teks. Berangkat dari realitas tersebut Teks "direkayasa" untuk mengatasi persoalan kemanusiaan. Dengan demikian pemaknaan atas Teks diarahkan untuk memberi arah gerak teologis bagi upaya pemecahan masalah-masalah kemanusiaan. Dalam pandangan Hassan Hanafi Teks harus menjadi landasan teologis bagi aksi kemanusiaan. Inti pandangannya yang spesifik adalah bahwa tafsir tidak berpretensi mencari makna universal, tetapi mencari makna temporal yang diberikan al-Qur'an pada generasi tertentu dengan mengabaikan kepentingan masa lalu maupun mendatang. Tafsir semacam ini selalu merujuk pada pengalaman penafsiran dan problem kontemporernya di mana lebih mengutamakan pada pemecahan masalah masalah sosial kemanusiaan (al-manhaj al-tafsir al-ijtima’i) dalam konteks kekinian. Aspek orisinilitas dari penelitian ini adalah pengkonstruksian kembali pemikiran Hassan Hanafi dalam
\end{abstract}


Millatī, Journal of Islamic Studies and Humanities, Vol. 5, No. 1, June 2020: 1-15

memahami al-Qur'an secara progresif berlawanan dengan mainstream utama penafsiran alQur'an di kialangan muslim.

Kata Kunci: Metodology, Hermeneutika, Tafsir Kemanusiaan, Tafsir Tematik.

\section{INTRODUCTION}

The development of contemporary hermeneutics, especially the emergence of Gadamer-style productive hermeneutics, has opened new horizons in reading texts (Qur'an). This method raises or accepts any prejudices that are valid in interpreting the Qur'an. ${ }^{1}$ This method has inspired a number of Muslim scholars to interpret the Qur'an. Even so, the hermeneutic outlook on the Qur'anic texts of these Muslim thinkers is unique.

In general, the methodological model can be divided into two groups as follows. First, those which set out with an effort to explain the meanings of the text more or less objectively and only then turn to the present reality for contextualization. This first group was mainly represented by Fazlur Rahman, Muhammad Arkoun, and Nashr Abu Zaid. Second, Muslim scholars who try to depart from the contemporary reality of Muslims towards understanding in accordance with the teachings obtained from the Tafseer of the Qur'an. The second group was represented by progressive thinkers such as Farid Esack, ${ }^{2}$ Asghar Ali Engineer, and Hassan Hanafi.

Hasan Hanafi is part of the second set of group that significantly contributes to Tafseer that is more progressive, grounded and liberated Muslims from the shackles of colonialism, capitalism and various forms of modern imperialism. He gives a discourse on transformative Tafseer in favor of humanity. In other words, Hassan Hanafi's model of Tafseer of the Qur'an provides more concrete guidance for the movements and actions of Muslim community change. In this case it can be said that the unique Tafseer of Hassan Hanafi lies in the progression of the movement and action. Thus, it is not too excessive and not too wrong if it is called a model of human Tafseer.

\footnotetext{
${ }^{1}$ Gadamer, H.S, "The Historicity of Understanding", in The Hermeneutics Reader, ed. K. Mueler Vormer, Continuum, New York, 1992, p. 261

${ }^{2}$ He proposed a hermeneutic model of interpretation of the Qur'an to pave the way to build a more human life by creating space for truth and justice and pluralism. See Farid Esack, Qur'an, Liberation, and Pluralism: An Islamic Perspective of Interreligious Solidarity Againts Oppression, Oneworld, Oxford, 1997, p. 14
} 
The term Tafseer of humanity itself is not so popularly used by writers who discuss the thoughts of Hassan Hanafi. This term is only a simplification of the word to represent a unique model of Tafseer which leads to theological movements and actions in answering the problems of the Muslim world. Some other writers prefer to use the terms realist Tafseer, ${ }^{3}$ leftist Tafseer, or thematic Tafseer.

\section{DISCUSSION}

\section{The Socio-Intellectual Setting of Hassan Hanafi}

The progressiveness of Hassan Hanafi's Tafseer cannot be separated from the influences and socio-intellectual background in which he is. In general it can be stated that Hassan Hanafi's thoughts are based on three important factors: (1) academic background and movement; (2) conditions of the Muslim world; and (3) Western supremacy.

From his educational background it is known that Hassan Hanafi was an alumnus of Sorbonne University, Paris, 1966. At this university he absorbed a lot of Western knowledge. He concentrated himself on the study of pre-modern and modern Western thought. He studied the thoughts of Spinoza, Voltaire, Kant, Hegel, Max Weber, Edmund Husserl, Karl Jaspers, Herbert Mercuse, and others. ${ }^{4}$ It was the ideas of Western thinkers which later influenced his liberal modernist thoughts, even though he rejected and criticized the West.

During his studies in Paris, he also participated in many of the struggles of French political thought. As it is known that since the French Revolution, radical groups took the left side of the Chair of the National Congress. Since then (in the West), the terminology of Right and Left is often used in the political sphere. The left is defined as parties that tend to be radical, socialist, reformist, progressive, or liberal. This term is then used by Hassan Hanafi to articulate his movement of Islamic Left (al-yasar al-islamiy). The Islamic Left intended by Hassan Hanafi is an ideological movement to elevate the position of the controlled, the oppressed, the poor and the oppressed. ${ }^{5}$ Although Hassan Hanafi was not the first to come up

\footnotetext{
3 See M.Mansur, "Metodologi Tafsir Realis: Telaah Kritis Terhadap Pemikiran Hassan Hanafi", dalam Abdul Mustaqim dan Syahiron Syamsudin (ed.), Studi al-Qur'an Kontemporer : Wacana Baru Berbagai Metodologi Tafsir, Tiara Wacana, Yogyakarta, 2002, p.97

${ }^{4}$ Hassan Hanafi, Qadhaya al-Mu'ashirah 2: Fi al- Gharbiy al-Mu'ashir, Dar al-Tanwir li al-Tibaah wa al-Nashr, Beirut, 1982. p. 23

${ }^{5}$ Hassan Hanafi, "Madha Ya'ni al-Yasar al-Islamiy" dalam al-Yasar al-Islamiy, Cairo, 1981, p. 7
} 
Millatī, Journal of Islamic Studies and Humanities, Vol. 5, No. 1, June 2020: 1-15

with the term Islamic Left, ${ }^{6}$ the identity of the ideology and the Islamic Left movement in the realm of Islamic modernism was generally attached to Hassan Hanafi.

Viewed from the side of the movement, young Hassan Hanafi (while studying in Tsanawiyab) actively participated in discussions of the Muslim Brotherhood group (with Sayyid Quthb), an organization that wanted to bring about the unity and progress of Muslims. Hassan Hanafi's dialectical process with the figures of this movement who later later joined in reinforcing the 'talk of progressive thought'. The works of Hassan Hanafi at the beginning of his intellectual career did not show a progressive Tafseer movement, towards the real action of the liberation movement. But later after struggling with activists in various Muslim movement organizations, ${ }^{7}$ the idea of his ideology of alignment with the oppressed (mustadh'afin) became more apparent.

One of the motivations why Hassan Hanafi immersed himself in the academic world as well as the movement was departing from his concern over the condition of Muslims who are in the cage of modern colonialism and imperalism. Islamic theology and classical Tafseer in particular - according to Hassan Hanafi - are not able to provide interpretative solutions that are able to guide the movement of Muslims in overcoming and fighting Western hegemony in the economic, political and cultural fields. Hassan Hanafi tried to offer a model of Tafseer to pave the way for the effort to ground God's text in human life. In other words, the emergence of humanistic Tafseer is motivated by the spirit to present God's message on earth, not on the contrary bringing the earth man to the heavens of God, as is the model of Tafseer developed among classical commentators. Therefore - as will be explained in the following sections - the Tafseer methodology starts from a theme that prioritizes solving humanitarian problems (waqiatu al-ula), to be confronted with the text. So the point of departure is that the Tafseer method departs from the human problem as an audience, the text is brought to the realm of human pre-understanding.

6 This term has already been used by AG. Shalih in 1972 to describe Islamic socialism. See Kasuo Shimogaki, Kiri Islam, Antara Modernisme dan Post Modernisme : Telaah Kritis Pemikiran Hassan Hanafi, terj. M. Imam Aziz dan M. Jadul Maulana, LKiS, Yogyakarta, 1997, p. 6

${ }^{7}$ Hassan Hanafi is also active in various scientific organizations such as: the Union of Egyptian Philosophy Societies, the Asian-African Writers Association, and the Asian-African Solidarity Association. See Kastolani, "Signifikansi Oksidentalisme Dalam Modernisasi Islam: Studi Analisis Pemikiran Hassan Hanafi", on Jurnal Penelitian Sosial Keagamaan Inferensi, Vol. 1, 2007, p. 247 
Up to this point to see the position of Hassan Hanafi in the constellation and setting of modern Muslim thinkers, then a picture of three faces (at once) found in Hassan Hanafi can be added. The first face of Hassan Hanafi was the figure of a revolutionary thinker. After the victory of the Iranian Islamic revolution, he focused his attention on the movements or thoughts of the Islamic Left, which were intended to achieve a monotheistic revolution. Thus it is not wrong if Hassan Hanafi is always positioned as a revolutionary Islamic thinker like Ali Shariati and Imam Khumaeni who are the key of the success of the Islamic revolution. ${ }^{8}$

The second face that is so thick with the figure of Hassan Hanafi is as a reformist figure in the classical Islamic intellectual tradition. In this respect, he resembles the position of Muhammad Abduh (a prominent Egyptian thinker, 1849-1905), especially in terms of reforming and rationalizing Islamic traditions. While the third face, Hassan Hanafi can be said to be the successor figure of Al-Afghani movement or thought (1838-1896). Al-Afghani himself was the founder of the modern Islamic movement which was so persistent in the struggle against Western imperialism and uniting the Islamic world. Hassan Hanafi, through his Islamic Left movement, also strongly opposed the Western cultural imperialism and was always progressive in pursuing the unification of the Islamic world. ${ }^{9}$

\section{The Characteristics of Hassan Hanafi's Thoughts}

The uniqueness of Hassan Hanafi's thoughts on other contemporary Muslim thought can initially be traced from his view of the causes of the decline of Muslims. According to him, Muslims backward because of three things: (1) loss of creative thinking due to being shackled by normative and doctrinal classical religious understanding; (2) dependency as well as inferior feelings toward the West; and (3) reluctance to see the reality of the current problems of Muslims. Hassan Hanafi's sensitivity to these three problems led him to develop a comprehensive cultural strategy, known as the project of tradition and modernization (al-turats wa al-tajdid).

Hassan Hanafi put the project of tradition and its modernization into three main agendas, namely our attitude towards tradition, our attitude towards the West and our attitude

\footnotetext{
${ }^{8}$ Kasuo Shimogaki, op.cit., p. 4

${ }^{9}$ Ibid., p. 4
} 
Millatī, Journal of Islamic Studies and Humanities, Vol. 5, No. 1, June 2020: 1-15

towards reality. ${ }^{10}$ The first pillar he explained with ibya 'al-turats, namely efforts to reconstruct, develop, and purify various components of discipline in the tradition and intellectual property of classical Islam. The discipline of Qur'an study and Tafseer is the most important thing besides ushul fiqh- to be revitalized with a critical Tafseer methodology.

The second pillar is dismantling the supremacy of Western civilization by returning the West to its natural limits. He carried out this agenda with the project of Occidentalism. One important point of Occidentalism is the attempt to break the myth that states that Western civilization is a single global civilization, and at the same time as a standard of civilization for other nations.

The third pillar is lifting the reality of the Islamic world. The reality of the Islamic world according to Hassan Hanafi is none other than the phenomenon of imperialism, capitalism, authoritarianism, poverty, oppression and backwardness. ${ }^{11}$ To lift the Islamic world from these phenomena, it can no longer rely on the classical textual normative Tafseer model. The Tafseer model that departs from the understanding of the text must be replaced with an understanding of reality. The realist Tafseer model carried by him uses the tools of phenomenology, sociology, history, and hermeneutics.

It seems that these three pillars are the basis of the methodology of interpreting his actions, while at the same time explaining the unique position of Hassan Hanafi's thought when compared to other contemporary Muslim thinkers. Muslim thinkers and (at the same time) Muslim activists such as Ali Shariati from Iran who were also friends of Hassan Hanafi in Paris, Ali Ashghar Engineer in India, Bassam Tibi in Germany, and Farid Essac in South Africa, ${ }^{12}$ are figures who have sensitivity to issues - real problems of Muslims such as poverty, oppression and colonialism. However, it can be stated that Hassan Hanafi's thinking model is the most comprehensive in making changes.

\footnotetext{
${ }_{10}$ M. Amin Abdullah, "Kata Pengantar", dalam Ilham B. Saenong, Hermeneutika Pembebasan: Metodologi Tafsir Menurut Hassan Hanafi, Teraju, Jakarta, 2002, p. xvii

11 Kasuo Shimogaki, op.cit., p. 122. See also on Hassan Hanafi, Bongkar Tafsir: Liberalisasi, Revolusi, Hermeneutik, terj. Jajat Hidayatul Firdaus dan Niela Diela Rochman, Prismasophie, Yogyakarta, 2005, p. 117

12 Farid Esack, on Qur'an: Pluralism and Liberation, menguraikan hermeneutika pembebasannya didasarkan atas keprihatinan pada realitas sosial masyarakat. See Fahruddin Faiz, Hermeneutika Al-Qur'an: Tema Tema Kontroversial, eLSAQ Press, Yogyakarta, 2005, p. 13
} 


\section{Tafseer Method of Hassan Hanafi}

As happened to other contemporary Muslim thinkers, the hermeneutic influence of Western academic traditions also colored Hassan Hanafi's Tafseer model. Even more correctly stated that the model of Hassan Hanafi's Tafseer is a combination of Tafseer and hermeneutic traditions.

According to Hassan Hanafi, the tradition of Tafseer in Islam has begun since the Qur'an was revealed. In general, classical Tafseers are built on a number of main Tafseer methods (manhaj al-tafsir al-asasiy). One example of Tafseer method is the linguistic method. The linguistic method has become the mainstream Tafseer methodology in the early days, where linguistic traditions (lughah, balaghah, fashahah, and bayan) were the main characteristics of the early days of Islam. This was motivated by the traditions of the Arab community at that time so familiar with the rhetoric and poetry. Thus it is quite rational if the linguistic Tafseer method was born as a characteristic of the times. Besides that, Qur'an itself is also a book of balaghah which can be used for linguistic authority such as classical Arabic poetry, rhetoric, and Arabic tamtsil. In fact, it can also be said that the process of converting Arab society to Islam cannot be separated from the tradition of linguistic and eloquence of the Qur'an. ${ }^{13}$

After that, Tafseer through historical methods or can be called Tafseer based on historical authority (tafsir bi al-ma'tsur), began to dominate. This new tradition began to emerge when the authority of knowledge mostly came from tradition and history, the glorification of ashab, tabi'in, and tabi'i al-tabi'in, prioritizing early generations over later generations, prioritizing salaf on khalaf, promoting relics and preserving turats. ${ }^{14}$

Fiqh method is dominant in the Tafseer of the Qur'an in the way of fiqh to establish Islamic law. These Tafseers grew during the codification period of sharia, mentioning differences between various schools and the birth of religious schools of fiqh by trying to build small madzhabi states, which need political and social system. Some important things during the fiqh method include: (1) that revelation has been derivated into sharia; (2) there is a transcendence of differences in dogmatic fiqh schools to tasyri '; and (3) the diversity of fiqh Tafseers has led to agreement on submission to the main maqashid al-syariah namely maslahah

\footnotetext{
${ }^{13}$ Hassan Hanafi, Metode Tafsir dan Kemaslahatan Umat, terj. Nuwasea, Yogyakarta, 2007, p. 19

${ }^{14}$ Ibid., p. 22
} 
Millatī, Journal of Islamic Studies and Humanities, Vol. 5, No. 1, June 2020: 1-15

(benefit). ${ }^{15}$ Besides that there are still sufistic methods as seen in Sufistic Tafseers, both total and particular. The birth of this mystical Tafseer was motivated by the rejection of the thought of the kalam schools which at that time tended to be trapped in political pragmatism.

Hassan Hanafi outlines some strength of each interpretive method, but once he points out the weak points of traditional Tafseer are too long-winded and tend to be repetitive so that Tafseer does not pay attention to needs. This means that the traditional Tafseer does not begin with the formulation of the problem whether or not the Tafseer is needed. ${ }^{16}$ Whereas according to Hassan Hanafi, the main motive of Tafseer is not merely to explain the entire Qur'an as a text, but the main motive is to explain the empirical reality as the basis for the birth of the text. The argument from this opinion is that the text would not have been born without reality as its determinant. So it is not revelation (text) that causes the birth of various empirical events (reality), but on the contrary, reality is the birth of the text. In other words, there is a supremacy of reality over revelation (text), because reality will always be a reference to the text, without which this reference of the text will become void of meaning. ${ }^{17}$

The meaning of the text dealing with the context on Hassan Hanafi model seems to be framed by Gadamer's hermeneutic understanding. One of the main characteristics of Gadamer's approach in relation to the Tafseer of texts lies in his assumption that Tafseer cannot be free from interpreter's subjectivity which is then called pre-understanding or awareness influenced by history. ${ }^{18}$ The main concept of Gadamer asserted that every human understanding is always based on previous understanding as well as understanding of what is needed and what is the purpose of the interpreter. It is this kind of background of understanding which then gives the interpreter certain choices of meaning.

The foundation of Hassan Hanafi's Tafseer methodology is laid on several premises that must be adhered to: First, that the text of the Qur'an does not need to be questioned about its origin or nature. Second, the Qur'anic text must be treated as a linguistic text in general. Third, the Tafseer does not recognize the normative assessment of right and wrong, because the

\footnotetext{
15 Ibid., p. 27

${ }^{16}$ Hassan Hanafi, Qadhaya Mu'ashirah fi Fikrina al-Mu'ashir, Vol. II, Dar al-Tanwir, Beirut, 1983, p. 175

${ }^{17}$ Hassan Hanafi, al-Din wa al-Tsaurah, Vol. VIII, Maktabah Madlubi, Cairo, 1981, p. 45. See also Hassan Hanafi, Oposisi Pasca Tradisi, translation. Khoiron Nahdliyyin, Syarikat Indonesia, Yogyakarta, 2003, p. 29

18 See Inyiak Ridwan Munir, Hermeneutika Filosofis: Hans Georg Gadamer, Ar-Ruzz Media, Yogyakarta, 2008, p. 130. Lihat juga Jean Grondin, Sejarah Hermeneutik: Dari Plato Sampai Gadamer, translation. Inyiak Ridwan Munir, Ar-Ruzz Media, Yogyakarta, 2007, p. 174
} 
ideological subjectivity of the interpreter and the context of Tafseer is a necessity. Fourth, there is no single Tafseer of the text, but instead there are many Tafseers given by many different interpreters. Fifth, conflicting Tafseers are basically more socio-political conflicts than theoretical conflicts. ${ }^{19}$

With the five premises above, Hassan Hanafi formulated methodical steps in interpreting the Qur'an. First, an interpreter must consciously know and formulate his commitment to certain socio-political problems. This means that Tafseer always starts with concern for the condition of the community. Second, departing from the awareness of the reality above, the interpreter must formulate the Tafseer goal. Third, from the formulation of the goals and commitments an interpreter then inventory the verses related to the problem (theme) which becomes his commitment. Fourth, do the classification of related verses on the basis of linguistics. Fifth, form the structure of the right meaning with the intended Tafseer of the goal. Sixth, identification of the actual problems faced by the interpreter, can be in the form of oppression, inequality, injustice, and so on. Seventh, linking the ideal structure as a result of text deduction with factual problems induced from empirical reality through statistical calculations and social science. Eighth, building a practical formula as the final step in the process of transformative Tafseer. ${ }^{20}$

Judging from the methodical steps taken in Tafseer, it seems that Hassan Hanafi wants to emphasize that Tafseer does not pretend to seek universal meaning, but looks for the temporal meaning given by the Qur'an to certain generations that ignores past and future interests. This kind of Tafseer also always refers to the experience of Tafseer and contemporary problems which place more emphasis on solving social humanitarian problems (al-manhaj al-tafsir al-ijtima'i). The direction of Hassan Hanafi's Tafseer seems to provide guidance for more progressive humanitarian action.

\section{The Example of Hasan Hanafi's Tafseer}

To give an overview of the Tafseer methodology of Hassan Hanafi, the following is an example of the Tafseer about humans (al-nas), assets (al-mal) and land (al-ard).

\footnotetext{
${ }^{19}$ Hassan Hanafi, Islam in The Modern World : Religion, Ideology and Development, Dar KebaaBookshop, Cairo, 2000, pp. 485 - 486

${ }^{20}$ Ibid., p 105-106
} 
Millatī, Journal of Islamic Studies and Humanities, Vol. 5, No. 1, June 2020: 1-15

In the Qur'an, the words al-nas, especially in the singular (al-insan) which show the meaning of individuality, are mentioned 65 times. Whereas in the plural form (unas), which shows the meaning of a group of humans, is mentioned 6 times. Once in the form of the word ins which means man in the singular, and once in the form of the adjective-verbal (al-musta'nas) which means intimacy, closeness, and kinship. Whereas in substance, the meaning of al-nas can be categorized into 5 orientations of meaning; (1) The depictions of humans created from nothing (ex-nibilo) are mentioned 12 times in the Qur'an. Humans were created from clay or sperm. Humans are also created from knowledge. As such, knowledge is the foundation of human existence itself; (2) The depiction of humans consisting of psychological structures, mentioned in the Qur'an 33 times. Humans are weak, frightened, unconscious of time, motivated, and moved by lust. People will come to ask for help in times of crisis, but they forget to come when a crisis passes. Humans can feel happy and unhappy, like hope and always hopeless, generous and greedy, strong and weak, consistent and inconsistent, and remember and forget. Even the Qur'an also illustrates that humans can be enemies, dictators, arrogant, immoral, stubborn, doubtful, speculative, and suspicious. (3) Humans are hostile to an enemy who does not recognize human meaning, and does not recognize human potential and honor. (4) Man is responsible, so man is greater (noble) than heaven, nature and mountains. Human existence is seen when they pass or fail the exam. (5) A successful person is a person who is successful in turning weaknesses into strengths. Humans are individually responsible. $^{21}$

The word Al-Mal as stipulated in the Qur'an is not always interpreted as money in the literal sense, but it can also be interpreted as wealth or ownership in general. In various forms, the word al-mal in the Qur'an is mentioned 86 times. The word al-mal related to as a substance is mentioned 32 times. While those related to ownership are mentioned 54 times. This shows that wealth can also be outside of private ownership.

Etymologically, the word al-mal itself is not substance but rather tends to be a relative pronoun ma associated with the preposition $l i$ which means mine. This word is mentioned 17 times, with details in the indefinite (not certain) form and 15 times in the definite (certain) form. This shows that the so-called wealth can be known as well as cannot be known. Thus, it

\footnotetext{
${ }^{21}$ Hassan Hanafi, "Dari Teks Ke Aksi: Merekomendasi Tafsir Tematik", on Jurnal Studi Al-Qur'an, Vol I, 2006, pp. 72-73
} 
can be said that the wealth referred to above is not the subject (al-mubtada') or predicate (al$k h a b r)$, but as an object for the subject and predicate.

In addition, the word al-mal itself is also often associated with the nature of ownership, on single/first person (mentioned 7 times), plural/second and third person (47 times). This shows that the wealth is more likely as a collective ownership in the name of the non-owned, those whose rights are deprived, as well as the poor and orphans. The first person singular mentioned above shows the upper class, the second person refers to the middle class, while the third person denotes the lower class. About the contents, there are three meanings orientations. (1) wealth, ownership and inheritance belong to God, not humans, all of that is only entrusted to humans as trusts. (2) humans have the right to use property not to be wasted, to be invested not to be stockpiled, to be spent not to be wasted, to build and defend themselves. (3) the independence of human consciousness vis a vis wealth, making wealth a simple tool for human perfection. Wealth for humans, not humans for wealth. ${ }^{22}$

The word al-ardh in the Qur'an is mentioned 462 times and 456 times it appears in the meaning of substance. If related to the adjective ownership, the word al-ardh only appears 8 times. This shows that the land is not included as an object of ownership. Land or al-ardh in the possession of food only appears once and is associated with the first party (God). Thus it can be understood that only God has the right to assume ownership of the land or al-ardh itself. While in terms of the orientation of meaning, in the word al-ardh there are five things namely; (1) God is the sole owner of the land (earth) or al-ardh, and also the sole trustee; (2) alardh or land is a symbol of fertility and beauty. The level of human productivity in utilizing land symbolizes the high creativity of human life itself. In addition, land is not only a land of human creativity, but is also intended for all living things in the world. Thus it can be understood that the meaning of al-arh or land in this context can be interpreted as an arena for creatures to integrate, conflict, create, and experiment while creating history on earth as a form of proof of human obedience and to fulfill God's call on earth; (3) Opportunities for all humans are entirely given up on earth, remembering that God is the Lord of heaven and earth. Thus it can be said that humans are God's representatives on earth. Because, God does not interfere directly on earth. God transfers the 'rights' of land to human hands so that humans are free to

22 Ibid., pp. 74-75 
Millatī, Journal of Islamic Studies and Humanities, Vol. 5, No. 1, June 2020: 1-15

uphold truth and justice, because land has the meaning of objective truth as the foundation of nature; (4) Human existence on earth begins with a belief in a unity that manifests itself in the transfer of God's right. However, the transfer of rights by God to humans is not an absolute right but must be accounted for by all people with the program to carry out management always based on faith and piety. Thus, humans should use, care for and protect the land and not be exploited and then destroyed. That is what is called responsible land use or processing; (5) every individual has ever agreed on a universal agreement (not a special agreement), a moral agreement (not a material agreement), and a contractual agreement (not a unilateral agreement). ${ }^{23}$

\section{CONCLUSION}

The Tafseer method of Hanafi brings together the interpretive tradition in Islam and Western hermeneutics. The thematic Tafseer of Hassan Hanafi is one of the answers to the famine of progressive Tafseer thinking. Hassan Hanafi's thematic Tafseer moves from the eclectic process of reducing the meaning of the text, while simultaneously inducing reality. ${ }^{24}$ In reading Hassan Hanafi, reality must speak in its own name. Hermeneutics in this case can be used to explain the process of receiving revelation from the word level to the reality level, from logos to praxis.

Hassan Hanafi proposed a specific method of hermeneutics of the Qur'an (juz'i), thematic (maudhu'i), temporal (zamani), realistic (waqi' $i)$, and emphasized more on meaning and purpose than words and letters only. The hermeneutics of the Qur'an must always be based on the experience of life in which the interpreter lives, and begins with a study of the problems of humanity. The hermeneutic theory is mainly based on the understanding of asbab al-nuzul, in the sense that reality always precedes revelation. Tafseer must take its starting point from reality, in the problems where humans get themselves, and then return to revelation (Qur'an) to get a theoretical answer (logos). This theoretical answer must then be applied in praxis. Tafseer always ends in praxis. ${ }^{25}$

\footnotetext{
${ }^{23}$ Ibid., p. 76

${ }^{24}$ Ibid., p. 59

25 See Moch. Nur Ichwan, Meretas Kesarjanaan Kritis Al-Qur'an: Teori Hermeneutika Nasr Abu Zaid, Teraju, Jakarta, 2003, p. 39
} 
It must be acknowledged that the model of Tafseer of Hassan Hanafi's action is quite significant in guiding the movement for change in Muslim societies. Even so, this model is also not free from several issues as well as objections from Conservative Muslims. ${ }^{26}$ First, in looking at the text of the Qur'an, Hassan Hanafi holds that without making a distinction between sacredity and profaneity, between transcendence and immanence, and between religious and secular, this can make people reject revelation and deny prophecy. Second, the Tafseer views the Qur'anic text as relativistically rejecting the claim of the "most correct" Tafseer in all space and time. When the commentator at one time interpreted the Qur'an in accordance with the interests of his time, then the effort to explore the eternal meaning of the Qur'an would not be able to do. Human desires and inclinations (subjectivity) can distance the mufassir from the objectivity of the meaning of the Qur'an itself. Third, the Tafseer is influenced by Marxism which glorifies the defense of the oppressed, the poor and those marginalized by unjust social structures. Fourth, Hassan Hanafi's Tafseer puts forward the philosophical tools of language and vocabulary techniques and deals with phenomenology. This Tafseer can become a victim of rationalism, humanism, criticism imported from the West.

Against the objections above, Hassan Hanafi provided arguments. (1) Against the first objection, it is stated that the text descended in a certain time and space in order to be understood by the community who are in certain socio-political settings to change the situation of the community for the better. So there are human and social manifestations in revelation. (2) With regard to the second problem, he states that the eternal meaning of the Qur'anic text takes the form of hypotheses, assumptions and theoretical cases that are practically unknowable. A mufassir may claim to give the eternal meaning of the Qur'an, but that is not possible, because there will be no theoretical validity. (3) Against the third objection, he states that the thematic Tafseer starts from reality. The reality of the Muslim world is in the clutches of colonialism, oppression, social injustice, mal-distribution of wealth, ownership, ignorance, dictatorship, tyranny, autocracy. It is very clear that this model appears with jargon similar to Marxism. The background situation of the emergence of Marxism is more or less similar to the background behind the emergence of thematic Tafseers. Therefore, when the West is considered the only source framework, then thematic Tafseers are then considered as

${ }^{26}$ Some critics of Hassan Hanafi from conservative Muslims include: Muhammad Imarah, and Shobur Sahin. See, http: //www.insist.com. 
Millatī, Journal of Islamic Studies and Humanities, Vol. 5, No. 1, June 2020: 1-15

Marxism. Though Islam was originally embraced by the oppressed and the outskirts of Mecca.

(4) With regard to the third criticism, Hassan Hanafi regards it as something very cruel, because it gives too much the impression of Western monopoly. The values of humanism, rationalism and criticism are universal values in every age, not Western values. ${ }^{27}$

In the writer's opinion, criticism of Hassan Hanafi's thoughts needs to be focused (especially) on two main points: first the idea of hermeneutics which places the Tafseer of reality precedes the text, has negated the objectivity of God's text, so that the meaning of this text is as if nothing is certain, nothing can be held except the subjectivity of meaning itself. In the Kant tradition, subjectivity of knowledge must be limited because if it is not bounded, it will block the path of faith. The Tafseer of reality that is not given a frame of faith in the text of God seems to find uncertainty in reality. The second criticism, lies in the way of the discourse of interpretive thinking which is always carried to the "left". The extreme left manifestation as Karl Marx once conceived, in the course of the history of humanity apparently did not always have an impact on the benefit, but Marx's own allegation turned out to have caused a bad situation which ultimately led to disaster, not benefit as the logos.

\section{REFERENCES}

Esack, Farid, Qur'an, Liberation, and Pluralism : an Islamic Perspective of

Interreligious

Solidarity Againts Oppression, Oneworld, Oxford, 1997

Faiz, Fahruddin, Hermeneutika Al-Qur'an: Tema - Tema Kontroversial, eLSAQ Press, Yogyakarta, 2005

Grondin, Jean, Sejarah Hermeneutik: Dari Plato Sampai Gadamer, translation. Inyiak Ridwan Munir, Ar-Ruzz Media, Yogyakarta, 2007

Hanafi, Hassan, Qadbaya al-Mu'ashirah 2: Fi al- Gharbiy al-Mu'ashir, Dar alTanwir li al-Tibaah wa al-Nashr, Beirut, 1982.

-----------------, al-Yasar al-Islamiy, Cairo, 1981

---------, Metode Tafsir dan Kemaslahatan Umat, translation. Nuwasea, Yogyakarta, 2007

${ }^{27}$ Hassan Hanafi, op.cit., p 77 
----------, Qadhaya Mu'ashirah fi Fikerina al-Mu'ashir, Vol. II, Dar al-Tanwir, Beirut, 1983

--- al-Din wa al-Tsaurah, Vol. VIII, Maktabah Madlubi, Cairo, 1981

---------, Oposisi Pasca Tradisi, terj. Khoiron Nahdliyyin, Syarikat Indonesia, Yogyakarta, 2003

------- Islam in The Modern World : Religion, Ideology and Development, $\quad$ Dar

KebaaBookshop, Cairo, 2000

------------,Bongkar Tafsir: Liberalisasi, Revolusi, Hermenentik, terj. Jajat

Hidayatul Firdaus dan Niela Diela Rochman, Prismasophie, Yogyakarta, 2005

Ichwan, Moch. Nur, Meretas Kesarjanaan Kritis Al-Qur'an: Teori Hermeneutika Nasr Abu Zaid, Teraju, Jakarta, 2003

Munir, Inyiak Ridwan, Hermeneutika Filosofis: Hans Georg Gadamer, Ar-Ruzz Media, Yogyakarta, 2008

Mustaqim, Abdul dan Syahiron Syamsudin (ed.), Studi al-Qur'an Kontemporer : Wacana Baru Berbagai Metodologi Tafsir, Tiara Wacana, Yogyakarta, 2002

Saenong, Ilham B, Hermeneutika Pembebasan: Metodologi Tafsir Menurut Hassan Hanafi, Teraju, Jakarta, 2002

Shimogaki, Kasuo, Kiri Islam, Antara Modernisme dan Post Modernisme : Telaab Kritis Pemikiran Hassan Hanafi, translation. M. Imam Aziz dan M. Jadul Maulana, LKiS, Yogyakarta, 1997

Vormer, K. Muler, (ed.), The Hermenentics Reader, Continuum, New York, 1992

Jurnal Penelitian Sosial Keagamaan Inferensi, Vol. 1, 2007

Jurnal Studi Al-Qur'an, Vol 1, 2006 